\title{
Ankündigungen
}

\section{International Ornithological Congress XXII}

The XXII International Ornithological Congress will be held in Durban, South Africa, from 16-22 August 1998. The following Officers were elected: Honorary President, Tso-Hsin Cheng; President, Professor Peter Berthold; Vice President, Dr. Janet Kear; Secretary, Professor Walter J. Bock. Dr. Aldo Berruti, Department of Ornithology, Durban Natural Science Museum, Durban, South Africa, was appointed the Secretary General for this congress. The Scientific Programm Committee for the XXII Ornithological Congress has been appointed under the Chairmanship of Dr. Lukas Jenni, Swiss Ornithological Institute, $\mathrm{CH}-6204$ Sempach, Switzerland (Fax number +41-41-99 40 07; from 4 Nov. $1995+41-41-46297$ 10) and includes the following members: C. J. Bibby, U. K.; C. J. Brown, Namibia; A. Chandola-Saklani, India; T. M. Crowe, South Africa; D. G. Homberger, USA; A. P. Møller, Denmark; A. J. van Noordwijk, The Netherlands; Y. Ntiamoa-Baidu, Ghana; V. A. Payevsky, Russia; F. Spina, Italy; L. G. Underhill, South Africa; J. C. Wingfield, USA, in addition to the President, the Secretary General and the Secretary. The Scientific Program Committee will meet in Durban in early October 1995 to plan the scientific program for the XXII Congress including plenary speakers, symposia and their conveners. If you have any ideas and suggestions for the program, please send them to Lukas Jenni as soon as possible. If you would like to propose a symposium, please the following information to Lukas Jenni as soon as possible, but no later than 31 August 1995: title of the symposium, two conveners (you can propose yourself), a short statement (less than one page) outlining the overall subject to be covered by the symposium, a list of possible speakers with titles or tropics for each talk (5 talks per symposium). Symposia are intended for the general ornithologist rather than the specialist. Therefore, speakers should give review papers on recent developments in the field integrating ideas and findings, rather than talks on a single specialized study. Conveners should try obtain an international representation of speakers and a broad coverage of the subject of international relevance. Proposals for symposia for the last congresses greatly outnumbered the number of slots available in the timetable and it is important that the proposals are clearly presented to the committee. If a person agrees to convene a symposium or to give a talk at a symposium, he/she is committed to attend the Congress. A person can contribute as a first author to only symposium talk. Round Table Discussions are for discussion between specialists and are not to be used for a formal series of presented talks. Applications for Round Table Discussions will be requested later in the general congress brochure. Questions about the scientific program may be directed to the officers mentioned above or to any member of the Scientific Program Committee

\section{Fachtagung „Tiere und Pflanzen der frühen Kulturlandschaft”}

Vom 22./23. 3. 1995 veranstaltet die Gesamthochschule Paderborn, Abt. Höxter, Lehrgebiet Tierökologie, und die Arbeitsgruppe Artenschutz Thüringen e. V. in Neuhaus im Solling eine Tagung zum obigen Thema. Anmeldung: Universität/Gesamthochschule Paderborn, Abt. Höxter, Prof. Dr, B. Gerken, An der Wilhelmshöhe 44, D-37671 Höxter (Fax 05 27/16 82 00).

\section{Internationale Tagung „Fragen der Wiedereinbürgerung von Pflanzen und Tieren”}

Die Tagung veranstalten vom 21. bis 23. 4. 1995 die Arbeitsgruppe Artenschutz Thüringen e. V. und die Gesamthochschule Paderborn, Abt. Höxter, in Bad Blankenburg (Thüringen). Anmeldung von Referaten, Postern und zur Teilnahme an: M. Görner, Thymianweg 25, D-07745 Jena (Fax 03 64/60 56 25). 